\title{
Relocation and Livelihood Concerns of Sariska Tiger Project, Rajasthan: A Pride or Plight?
}

\author{
Dr Muraree Lal Meena ${ }^{\dagger}$
}

\section{Abstract}

It is well known that Sariska Tiger Reserve is a home to the India's national animal - the Bengal Tiger (Panthera tigris tigris). The crux of this research is to examine the role of local peoples in the conservation of Sariska Tiger project, which was declared a wildlife reserve way back in 1955 and then further raised to a status of a Tiger Reserve in 1978, and a National Park in 1982. According to the Government officials, the people around the reserve are not only responsible for degrading the reserve, it has also emerged as a safe haven for the poachers involved in illegal hunting of the tigers. One of the reasons identified to be the cause of tiger extinction is the human habitation in the core and in the peripheral areas surrounding the tiger reserves. Despite efforts being made to protect, the Sariska Tiger Reserve, located in Alwar (Rajasthan) is seriously facing the problem of tiger extinction. It is estimated that there are around 12 thousand people residing inside the tiger reserve, with 11 villages in the Core Zone-1 area and about 170 villages situated along the peripheries of the reserve. Among the prime measures undertaken are diversions of traffic, relocation of the villages located inside the forest. The Tiger Task Force (2005) has recommended relocation of three key villages surrounding the central area of the Sariska Tiger Reserve.

However, this relocation of villages is quite contrary to the life style of the people residing within these villages. Their social and cultural attributes, needs and aspirations have not been given due consideration and the villagers are strongly resenting this move by the government. These displaced villagers have been living in perfect harmony with their environment from time immemorial and it is hard to understand how these villagers can be held responsible for degrading their natural environment, which is their lifeline. The government has failed to take into consideration the role of the neighbouring urban centres that are more responsible for the degradation of the habitat as compared to these simple villagers. In the light of these arguments, this research is an attempt to study and highlight the issues and problems related to the displacement of villages in the core area of the reserve and suggest suitable measures.

Keywords: Displaced People, Conservation, Sariska Tiger Project, Harmony, Relocation and Livelihood.

\footnotetext{
${ }^{\dagger}$ Assistant Professor, Department of Geography, Faculty of Science, Banaras Hindu University, Varanasi, Uttar Pradesh, India-221005 Email: muraree.meena@gmail.com

(C) 2015 Meena. This is an Open Access article distributed under the terms of the Creative Commons Attribution License (http://creativecommons.org/licenses/by/2.0), which permits unrestricted use, distribution, and reproduction in any medium, provided the original work is properly cited.
} 


\section{Introduction}

The basic attitude underlying the reserved areas management is the conventional isolationist approach (without anthropogenic disturbances) of conservation, whereas, field study observations show that the society nature interface in the region is based on people's culture and religious values, which indicate that people support nature (Udaya, 2003). Located in the Alwar district of Rajasthan, the Sariska Tiger Reserve (STR), a home to Royal Bengal Tiger was declared a wildlife reserve in 1955 and a Tiger Reserve in 1978 and further a National Park in 1982 under the Wildlife Protection Act of 1972. The local people have demarcated the area of the forests as a Dev-Van (forest of God) and sacred forests that requires conservation. Most of these sacred forests have more diversity of species and safely harbour wildlife. The management of Sariska reserve is not proactive in forest resource development. The Wildlife Protection Act, 1972 too restricts infrastructure development of protected forest activities. Despite the lack of proper infrastructure and services, the geographical location of Sariska reserve, rich in biodiversity and being in close proximity to the national capital region (NCR), continue to attract wildlife enthusiasts. The key purpose of the research however, is to investigate the local inhabitants' role in conservation of this Tiger Reserve. It aims to examine how the local people can be actively involved and play role in conservation and development. If properly developed and managed, wildlife and forest resource could be an important source of income for local management and communities.

Notwithstanding, relocation of human populations from protected areas (notified for wildlife conservation) has been undertaken in several countries, as a means of trying to reduce pressures on wildlife. India is one of the countries where the issue of relocation has lately acquired centre-stage in the debates on conservation. Between 1969 and 2011, the area under National Parks and Sanctuaries in India grew tenfold to $5 \%$ of the total landscape
(Rangarajan, 2001). This part of land was free of all human habitations and this is a critical aspect of conservation policy and cause of the conflict.

Conservationists and social scientists often examine the impact of various human uses of ecosystem and tend to assess the issue of relocation in terms of the viability of habitats, ecosystems and endangered species. Conflicts with residents inside the protected areas can be intense with high rates of loss of livestock and crops and even on occasion, of human lives (Madhusudan and Mishra, 2003).

Human habitation and uses of natural resources are prohibited or severely restricted within most of the protected areas. There are three to four million people living inside these protected/reserve areas of the country and several million more in nearby areas, whose livelihoods depend on natural resources from these protected/reserve areas (Kothari et al., 1995). These local communities often have unclear or unregistered right to natural resources and lands. Moreover, many basic facilities do not reach adequately to Gwadas (seasonal cattle camps) or villages located inside the reserves. Hence, local communities inside the protected areas have varying access to natural resources for survival and livelihoods, but often also live in a state of deprivation, extreme levels of poverty and in conflict with forest managers, who usually perceive them as being responsible for the loss of wildlife and forests. The next two sections follow the objectives of the research and the methodology deployed.

\section{Objectives}

This study investigates the impacts (both positive and negative) of relocation polices, livelihood issues and challenges of Sariska Tiger Reserve. Study analyses the forest dependency and livelihood conflicts faced by local forest communities. In addition, the study also assesses the impact of relocation process and the rehabilitation packages. 


\section{Methodology}

The present study is based on the analytical method, evaluation of the observable trends of displacement issues in and out of the reserve. The study is based on both primary and secondary sources of data. The field investigation methods were used with an interactive discussion and observation among the displaced villages of Sariska Tiger Reserve. Secondary sources of data were collected from the annual and programme reports of the forest departments (both State and Central governments), National Tiger Conservation Authority (NTCA) for the Sariska Tiger Reserve of Rajasthan. For this study, collected data and information were processed to extract quality information. In addition, suitable cartographic techniques were also used for representing and analysing the data and observations. Before going into the study area, I discuss the displacement related government policies.

\section{Government Policies Linked to Displacement}

There are few national and state laws and policies for governing displacement and relocation issues of local communities from those areas labelled as 'reserved'. These are:

Wild Life (Protection) Act, 1972: This Act was amended in 1982, 1986, 1991, 2003, and 2006 and provides for the creation of the different categories of reserved areas, limits the right to live inside the protected forest of national park and sanctuary categories, puts restrictions on harvesting of natural products, and establishes a centralised and exclusive management.

The Wildlife (Protection) Amendment Act, 2002: In the Wild Life (Protection) Act, 1972 (hereinafter referred to as the principal Act), for the long title, shall be substituted, namely: an Act to provide for the protection of wild animals, birds and plants and for matters connected therewith or ancillary or incidental thereto with a view to ensuring the ecological and environmental security of the country.
National Policy on Resettlement and Rehabilitation 2007: The objectives of the National Policy on Resettlement and Rehabilitation (2007) are to minimise displacement and to promote and as far as possible, non-displacing or leastdisplacing alternatives. This centrally sponsored scheme on reserved forest related relocation specifies that relocation should be voluntary and in conformity with the provisions of this national policy.

Centrally-Sponsored Schemes IDWH, 2008: Until 2008, relocation from reserved forest was funded through the centrally sponsored beneficiary oriented scheme for tribal villages of project tiger areas, national parks and wildlife sanctuaries, framed by the Ministry of Environment and Forests in 1989-90. The compensation package of ₹ 0.1 million under this scheme has been increased to ₹1 million in the scheme on "Integrated Development of Wildlife Habitats" (IDWH) (NTCA, Government of India, 2014).

The Wildlife (Protection) Amendment Bill, 2013: Whenever it appears to the State Government that an area, whether within a sanctuary or not, is, by reason of its ecological, faunal, floral, geo-morphological or zoological association or importance, needed to be constituted as a National Park for the purpose of protecting, propagating or developing wildlife therein or its environment, it may, by notification, declare its intention to constitute such area as a National Park.

The following section discusses the study area. After this, I go on to sketch about the ecstasy linked to the Tiger Reserve.

\section{Study Area}

As stated above, the STR lies between $27^{\circ} 05^{\prime} \mathrm{N}$ and $27^{\circ} 33^{\prime} \mathrm{N}$ and $76^{\circ} 17^{\prime} \mathrm{E}$ and $76^{\circ} 34^{\prime} \mathrm{E}$ (Figure 1). The terrain of STR is undulating with altitudes ranging from 270 to 720 meter above 
MSL and has narrow valleys. It is classified as a part of semi-arid zone of north-western India. The area is seasonally dry with an average annual rainfall of $620 \mathrm{~mm}$ and extremes of temperature with cold winters and hot summers. The forest cover is typically dry deciduous embracing more than 211 species of birds and includes, as noted above, the two major predators Tiger (Panthera tigris tigris) and Leopard (Panthera pardus). The other interesting feature of STR is the high density of ungulates including Sambar (Cervus unicolor), Chital (Axis axis) and the four-horned Antelope (Tetracerus quadricornis). Sariska is famous for both its spectacular mammal wildlife and its pastoralist populations, living inside the villages/hamlets scattered over the core of the reserve (Shahabuddin et al., 2007). The temples of Bhartihari, Pandupole and Narayani Mata are also situated within the STR.

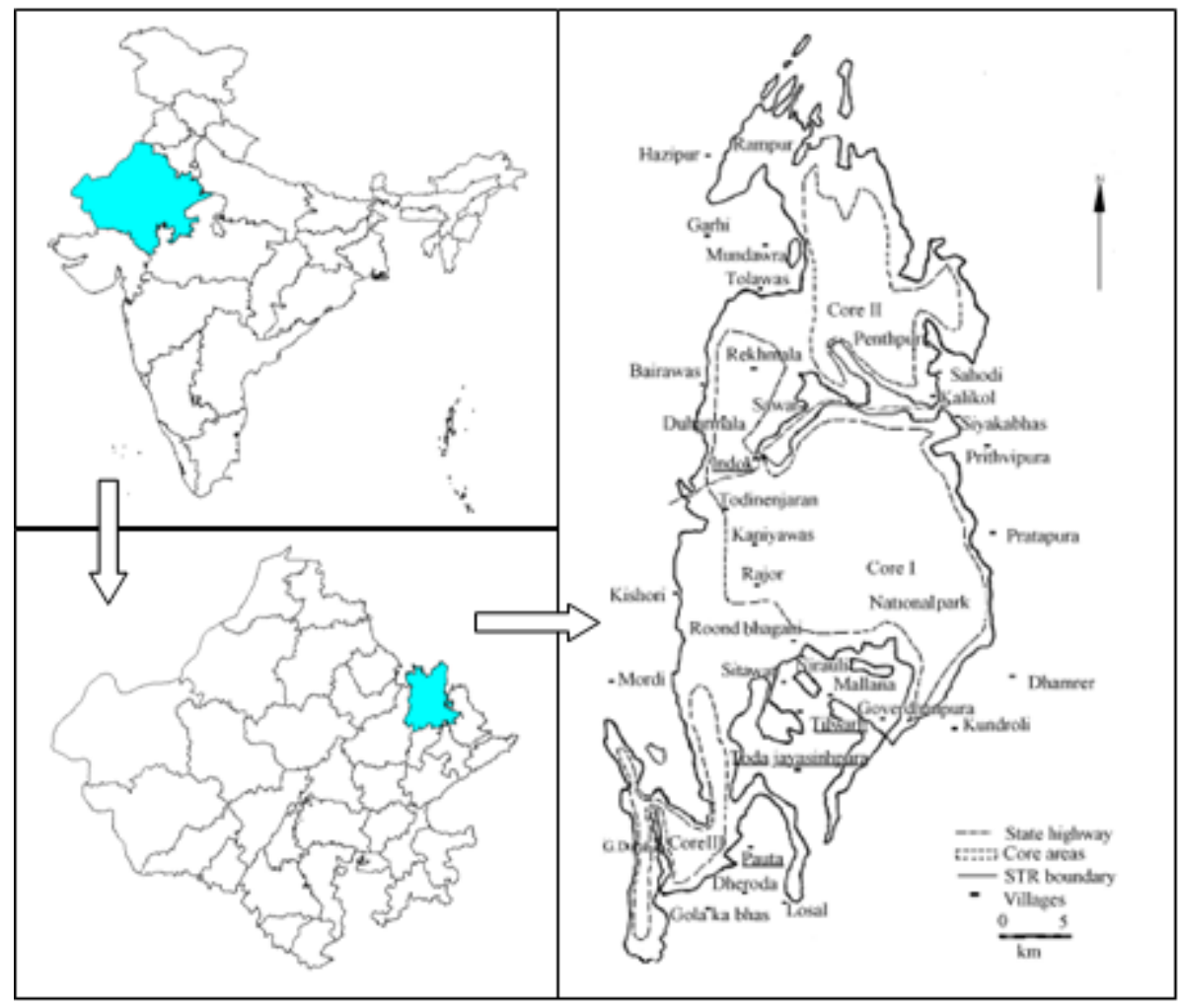

Figure 1: Location of Sariska Tiger Reserve (Source: Author)

\section{Sariska: Royal Ecstasy to Tiger Reserve}

The forests of Sariska were managed as a hunting reserve during the reign of the Maharaja of Alwar. Shooting blocks were maintained for big game hunting. There was a separate Shikarkhana and Shikar palatan to control and protect the area from poaching. Shooting was permitted until 1955, and Sariska was declared a reserved forest on 7 November 1955, under the Rajasthan Wild Animals and Birds Protection Act, 1951.

After Independence, the legal statutes of Sariska forest changed regularly through the passing of various acts and amendments of government policies. In parallel, the village relocation requirements and settlement process according to the changing statutes based on chronological development are illustrated in Table 1.

As mentioned above, Sariska was included in the list of the Tiger Reserves by Government of India in 1978 as the 11th Tiger Reserve. In 1982, 400.14 sq. $\mathrm{km}$ of the reserve has been preliminary notified as Sariska National Park.

According to the 2014 Census on Tigers, a little over 2226 tigers are left in India. Despite efforts being made to conserve the tigers via flagship conservation programmes such as Project Tiger/ Tiger Reserve, they continue to face the threat of extinction. That said, even after 45 
years of conservation efforts, the Sariska Tiger Reserve failed to have even a single tiger in 2005 (WWF-India, Feb, 2005). This is because during that time the forest officials misreported about the number of tigers and blamed on historical mismanagement (over mining, commercial extraction of trees, over tourism and local people living on the resources inside the reserve).

The lack of effective protection due to a crumbling administrative structure and prevalent corruption is completely sidelined in the current conservation efforts. Therefore, it can be observed that there has been no appraisal of the visible ecological damage caused by the failure of Sariska project management system (Shahabuddin et al., 2007). That failure has focused on translocation of tigers and village relocation as possibly the only tool to secure wildlife reserve.

Table 1: Legal Statues of Sariska and Settlement Process

\begin{tabular}{|c|c|c|c|c|}
\hline NP/WLS & Area & $\begin{array}{l}\text { Date of } \\
\text { Notification }\end{array}$ & $\begin{array}{l}\text { Section Under Which } \\
\text { Notified }\end{array}$ & $\begin{array}{l}\text { Settlement } \\
\text { Proceedings }\end{array}$ \\
\hline Reserve Forest & 456 sq. $\mathrm{Km}$ & Nov. 07, 1955 & $\begin{array}{l}\text { Wild Animals and } \\
\text { Birds Protection Act, } \\
1951\end{array}$ & $\begin{array}{l}\text { Displacement } \\
\text { not required }\end{array}$ \\
\hline Wildlife Sanctuary & 492.29 sq. $\mathrm{Km}$ & Sept. 18,1958 & $\begin{array}{l}\text { Sec.5 of the Wild } \\
\text { Animals \& Birds } \\
\text { Protection Act, } 1951 \\
\text { and Sec } 66(4) \text { of } \\
\text { WLPA,1972 }\end{array}$ & $\begin{array}{l}\text { Settlement not } \\
\text { required }\end{array}$ \\
\hline Project Tiger Reserves & 866 sq. $\mathrm{Km}$ & 1978 & $\begin{array}{l}\text { WLPA Act. Govt. of } \\
\text { India, } 1972\end{array}$ & $\begin{array}{l}11^{\text {th }} \text { Tiger } \\
\text { Reserve }\end{array}$ \\
\hline National Park & 400.14 sq. Km & Aug.27,1982 & $\begin{array}{l}\text { Sec. } 35 \text { of } \\
\text { WLPA,1972 }\end{array}$ & $\begin{array}{l}\text { Settlement } \\
\text { proceedings } \\
\text { not completed }\end{array}$ \\
\hline Critical Tiger Habitat & 881.11 sq. Km & Dec.28, 2007 & $\begin{array}{l}\text { Sec. } 38 \text { v W.L. Pr. Act } \\
1972 \text { amended in } \\
2006\end{array}$ & $\begin{array}{l}\text { Settlement } \\
\text { proceedings } \\
\text { not completed }\end{array}$ \\
\hline
\end{tabular}

Source: National Tiger Conservation Authority (2014), Mo EF, New Delhi: Government of India

Early Experiences of Village Relocation in Sariska

Initially, settlements of villages inside the protected Sariska reserve were organised under the Lamabardari system (this was a system of revenue collection wherein a person, the Lamberdaar was assigned the task of revenue collection from a revenue unit comprising of one or more villages) for enhancement of revenue collection from the forest products. After the 1958 declaration of Sariska as a wildlife sanctuary, during 1966-67, the forest department of Rajasthan relocated Slopka and Kalighati villages from the sanctuary. On 21 April 1976 a notification of the Rajasthan government denitrified the Rundh Bandipul and
Rundh Dulwa reserved forested lands into revenue lands for the purposes of relocation. Thereafter, in 1977 a systematic village relocation process started from the Sariska by the state government orders that 35 families from Karna Ka Was and 69 families from Kraska villages were relocated to Sirwas (near Silisere, Alwar district) and Bandipul (near Ajabgarh, Alwar district). Apart from cash compensation, lands were also allotted to the villagers. Thereafter, Kiraska was declared as the reserve forest land and villtagers were only given permission to performing religious activities at their sacred site and use the public road. Out of the 19 families of erstwhile Kraska, who were allotted land, nine sold off their lands and came 
back to the reserve along with the other landless people, mainly setting near the village known as Kundalka (Shahabuddin et al., 2007).

However, the villagers blamed the forest department for the debacle and alleged that the promises made to them regarding the new site were not fulfilled. They were neither provided the basic amenities at the site, nor the land was fit for cultivation (where, out of total $14 \%$ population involved in agriculture by occupation) at the time they settled there (Karanth, 2005). Moreover, they were compelled to accept whatever meager compensation they were given. According to the Forest Department Relocation Status Report (FDRSR), the total cash compensations of ₹120,975 were paid to 69 families of Kiraska village. Notwithstanding, even the villagers were compensated, and, at the same time, they were made to pay back the amount in most cases as pending penalties or dues of forest event.

\section{Recent Relocation Experiences: Society and Livelihood}

In 2005, it was declared that there were no tigers in Sariska. After that eight tigers were shifted from same climatic habitat region of Ranthambhor Tiger Reserve to Sariska (through trans-location), and now the number of tigers have grown to 13 . Tiger in Sariska National Park are roaring again but the danger for them has not subsided even after National Tiger Conservation Authority (NTCA) has spent millions of rupees for planning and their protection.

Nevertheless, the rehabilitation of villages from inside the park has been a complicated issue. In December 2002, the forest department has managed to shift only three villages namely Bhagani (19 families), Kankwari (110 families) and Umri (33 families), while 24 other villages still remains to be relocated. The package of rehabilitation in Sariska National Park contain ₹ 1 million cash to each family, but the villagers have failed to show interest as they fear to lose their livelihoods in the new place. During the 2009 to 2012, Deori (73 families) and Umari villages of the Core Zone-1 (out of a total of 11 villages) were shifted near the new site of Mojhpur Rundh.

The total population of the study area (Core Zone-1) villages is approximately 3200 , out of them, most villages (please refer to Table: 2) are inhabited dominantly by Gujjar communities (86.1\%). The other communities that inhabit these Core Zone-1 villages are Meena (7.6\%), Mew (3.2\%), Bawaria (1.7\%) and others (1.4\%).

Traditionally, these pastoralist communities (Gujjars, Mew, Bawarias and Meena ) are mainly engaged in the occupation of livestock grazing and selling of milk and milk products (71\%), some of them engaged in agriculture and daily wage labourer (14\%) as a secondary occupation. Few of them were also engaged in selling of livestock (6\%), army service (9\%), etc. Table 3 shows the occupation wise involvement of the communities in the Sariska Core Zone region.

During the interaction with these local people, we have observed that about $90 \%$ of the respondents complained that water accessibility is very poor at the new site of relocation. Here, the economy of village peoples becomes highly vulnerable both in the drought and in the famine conditions. The region witnessed a steep decline of average annual rainfall recorded during the last 12 years, which has resulted in decline of ground water level and surface water availability for agriculture or irrigation. Prior to displacement, all the families were actively involved in livestock and dairy works, whereas about 14\% were involved in agricultural activities.

However, after the process of displacement, the villagers failed to carry on their livestock and dairy occupations. Indeed, more than 95\% of the newly settled people began to depend upon agriculture as their source livelihoods. This occupational shift reflected negatively on income of the people. Indeed, according to the majority of respondents, the mean annual income of the people declined more than $40 \%$ of their earlier income (Shahabuddin et al., 2007). 
Table 2: Communities' Profile of Sariska Core Zone-1 (11 Villages)

\begin{tabular}{lll} 
Cast/ Communities & $\begin{array}{l}\text { Share in Total } \\
\text { Population } \\
\text { (in \%) }\end{array}$ & Villages \\
\hline Gujjars & 86.10 & $\begin{array}{l}\text { Kankawari, Bhagani, Dabali, Deori, Haripura, Karaska, } \\
\text { Kundalaka, Raikamala, Sukola, Umari and Lilunda. }\end{array}$ \\
\hline Meena & 07.60 & Deori, Karaska, Kundalaka \\
\hline Mew & 03.20 & Dabali \\
\hline Bawaria & 01.70 & Deori, Lilunda \\
\hline Others & 01.40 & Kankawari, Kundalaka \\
\hline Total & $\mathbf{1 0 0 . 0 0}$ & $\mathbf{1 1}$ Villages
\end{tabular}

Source: Data Analysed after Statistics Obtained from District Rural Development Authority (DRDA), Alwar, Rajasthan, September 2014

\begin{tabular}{cc}
\multicolumn{2}{c}{ Table 3: Sariska Core Zone: Occupation-wise Involvement } \\
\hline Nature of Occupation & Share of Income (in \%) \\
\hline Agricultural and Labourer & 14 \\
\hline Army/ Pension & 09 \\
\hline Selling of Livestock & 06 \\
\hline Selling of Milk and Milk products & 71 \\
\hline Total & $\mathbf{1 0 0}$
\end{tabular}

Source: Data Analysed after Statistics Obtained from District Rural Development Authority (DRDA), Alwar, Rajasthan, September 2014

\section{Suggestions and Conclusion}

Current relationship between local peoples and forest management in Sariska tiger reserve is marked by mistrust and non-cooperation. Whereas community participation based conservation, benefits-sharing with local people are being experienced as effective wildlife conservation as a rational approach instead of "fence and fine" approach of Indian forest bureaucratic system (Shahabuddin et al., 2007). Displacement of villages has clearly emerged as a critical issue in tiger conservation that needs to be examined far more closely than it has been in the past. The earlier relocation experience appears problematic and failure in its imposing nature of conservation policy.

It is urgently needed to rethink about Sariska relocation plans for the tiger conservation policy implementation. When displacement undertaken, the process should be participatory and decentralised in nature. In his urge for effective rehabilitation, Johari (2003) has suggested for insurance of the basic infrastructure facilities at the new relocation site, perhaps even before the beginning of the relocation process. Initially, the people were hesitant to shift from the reserve because of change in occupation and adaptation at new site for creation of livelihood alternatives. While Core Zone-1 area of $400 \mathrm{Sq}$. km. has significant potential for revival as a tiger habitat, having diverse forest types, permanent surface water and high density of native herbivores and revival of this Zone-1 can be completed only by relocating centrally located three villages (Bhagani, Kankwari and Umri) in the Sariska. However, it is also important to note that the protected core zones cannot be maintained without the cooperation and participation of the local communities. Therefore, the remaining 12 villages of core zones and 22 villages of the buffer zone can be productively envisaged as being a part of tiger and wildlife conservation of Sariska reserve. 
Here, in Sariska, the forest managers could avail better opportunities through active participation of the local communities. The involvement of the communities would help in guarding the forests from poachers. Besides community participation would help in reducing external extractive pressures that is currently threatening the reserve. Their participation can even be helpful in removal of any encroachments particularly religious structures and advancing agricultural fields in and around the reserve area. There is another need of attitudinal changes, sensitisation and developing motivation among the forest officials towards the local communities and their social and ecological concerns.

However, relocation of villages is quite contrary to the lifestyles of the people residing within these villages. These displaced people have been living in perfect harmony with their environment from time immemorial and it is hard to understand how these villagers can be held responsible for degrading their natural environment, which is their lifeline. This is a time to awake for the government and the forest managements to take into consideration the role of the peripheral villages and the neighbouring urban centres that are more responsible for the degradation of the Sariska habitat as compared to these innocent and responsible locale forest communities.

\section{Further Readings}

Cernea, M.M. (2006). Population Displacement inside Protected Areas: A Redefinition of Concepts in Conservation Politics, Policy Matters, 1(4), pp. 8-26.

Fernandes, Walter (2004). Rehabilitation Policy for the Displaced, Economic and Political Weekly, 39(12), pp. 1191-1193.

Government of Rajasthan (2004). Management Plan Sariska Tiger Reserve (2004- 2014): Project Tiger Sariska, Jaipur: Rajasthan.

Johari, R. (2003). Tigers and Invisible People: The Cultural Politics of Nature in Sariska Tiger Reserve, Rajasthan. In Ghazala Shahabuddin and M. Rangarajan (ed.), Making Conservation Work: Towards Innovative Strategies for
Securing Biodiversity in India, New Delhi:

Permanent Black.

Johnsingh, A.J.T., K. Sankar and S. Mukherjee (1997). Saving Prime Tiger Habitat in Sariska Tiger Reserve, Cat News, 27(3).

Kabra, A. (2003). Displacement and Rehabilitation of an Adivasi Settlement: Case of Kuno Wildlife Sanctuary, Madhya Pradesh, Economic and Political Weekly, 38(29), pp. 3073-3087.

Karanth, Krithi K. (2005). Bhadra Wildlife Sanctuary: Addressing Relocation and Livelihood Concern, Economic and Political Weekly, 40(46), pp. 4809-4811.

Kothari, A. (1997). Building Bridges for Conservation: Towards Joint Management of Protected Areas in India, New Delhi: Indian Institute of Public Administration (IIPA).

Kothari, A., S. Suri and N. Singh (1995). Conservation in India: A New Direction, Economic and Political Weekly, 30(43), pp. 2755-2766.

Kumar, R. and Ghazala Shahabuddin (2005). Effects of Biomass Extraction on Vegetation Structure, Diversity and Composition of an Indian Tropical Dry Forest, Environmental Conservation, 32(2), pp. 1-12

Madhusudan, M.D. and C. Mishra (2003). Why Big Fierce Animals Are Threatened: Conserving Large Mammals in Densely Populated Landscapes. In V. Saberwal and M. Rangarajan (ed.), Battles Over Nature: Science and the Politics of Wildlife Conservation, New Delhi: Permanent Black.

Mazoomdar, J. (2005 February.). No Evidence of Tiger in Sariska: WWF- India, Indian Express.

Ministry of Environment and Forests (2005). Joining the Dots, Report of the Tiger Task Force, New Delhi: Government of India.

National Tiger Conservation Authority (2014), MIS for Relocation of Villages- Sariska Tiger Reserve, Ministry of Environment and Forests, New Delhi: Government of India. 
Rangarajan, M. (2001). India's Wildlife History: An Introduction, New Delhi: Permanent Black and Ranthambhore Foundation.

Rangarajan, M. and Ghazala Shahabuddin (2006). Displacement and Relocation from Protected Areas: Towards a Biological and Historical Synthesis, Conservation and Society, 4(3), pp. 359-378.

Rodgers, W.A. (1990). A Preliminary Ecological Survey of Algual Spring, Sariska Tiger Reserve, Rajasthan, Journal of the Bombay Natural History Society, 87(2), pp. 201-209.

Shahabuddin, Ghazala, Ravi Kumar and Manish Shrivastava (2007). Creation of 'Inviolate space': Lives, Livelihoods and Conflict in Sariska Tiger Reserve, Economic and Political Weekly, 42(20), pp. 1855-1862.

Udaya Sekhar, N. (2003). Local people's attitudes towards Conservation and Wildlife Tourism around Sariska Tiger Reserve, India, Journal of Environmental Management, 69(4), pp. 339-347.

\section{Acknowledgements}

I would like to thank the anonymous reviewers and editorial board of this journal for their valuable feedback and constructive suggestions. 